This is the authors' accepted version of a manuscript due to appear in a forthcoming issue of Journal of Applied Research in Intellectual Disabilities

\title{
Postural care for people with intellectual disabilities and severely impaired motor
}

function: a scoping review

Janet Robertson $^{1}$, Susannah Baines ${ }^{1}$, Eric Emerson ${ }^{1,2}$ \& Chris Hatton ${ }^{1}$

${ }^{1}$ Centre for Disability Research, Division of Health Research, Faculty of Health and Medicine, Lancaster University, LA1 4YG, United Kingdom

${ }^{2}$ Centre for Disability Research and Policy, University of Sydney, PO Box 170, Lidcombe NSW 1825, Australia

Corresponding Author: Dr Janet Robertson PhD, Centre for Disability Research, Division of Health Research, Faculty of Health and Medicine, Lancaster University, LA1 4YG, United Kingdom.

Email: j.m.robertson@lancaster.ac.uk

Tel: +44 1524592895 Fax: +441524 592658

Acknowledgements: this work was supported by Public Health England. However, the findings and views reported in this paper are those of the authors and should not be attributed to Public Health England.

Conflicts of interest: none 
This is the authors' accepted version of a manuscript due to appear in a forthcoming issue of Journal of Applied Research in Intellectual Disabilities

\section{Abstract}

Background. Poor postural care can have severe and life threatening complications. This scoping review aims to map and summarise existing evidence regarding postural care for people with intellectual disabilities and severely impaired motor function.

Method. Studies were identified via electronic database searches (Medline, Cinahl, PsyclNFO and Web of Science) covering January 1990 to March 2016, and email requests to researcher networks. Results were collated via descriptive numerical summary of studies and thematic analysis.

Results. 23 studies were identified and summarised narratively in relation to three themes: characteristics and prevalence; interventions; and service related issues. The evidence base is small with significant gaps. Lack of evidence for night time positioning equipment and 24-hour postural care needs to be addressed urgently.

Conclusion. Future research should be clearly directed towards ascertaining how best postural care interventions can be employed to help improve the health and quality of life of people with intellectual disabilities.

Keywords: postural care; intellectual disabilities; scoping review 
This is the authors' accepted version of a manuscript due to appear in a forthcoming issue of Journal of Applied Research in Intellectual Disabilities

\section{Introduction}

A postural management programme has been defined as: “... a planned approach encompassing all activities and interventions which impact on an individual's posture and function. Programmes are tailored specifically for each child and may include special seating, night-time support, standing supports, active exercise, orthotics, surgical interventions, and individual therapy sessions" (p.244 Gericke, 2006). More recently, postural care (the term adopted in this review to include all the individual components of a postural management programme outlined above) has been defined as a way of preserving and re-establishing body shape for people with movement difficulties (RCGP, 2012). The biomechanics of body shape distortion and the use of therapeutic positioning to prevent body shape distortion has recently been summarised (Hill and Goldsmith, 2010). Validated indices to measure symmetry have also been developed (Goldsmith et al., 1992) which increase sensitivity to the early signs of asymmetry, and indicate the therapeutic positioning needed to protect and restore body shape (Goldsmith and Goldsmith, 2013).

Poor postural care can have severe and life-threatening complications for people who have a limited ability to change position (Crawford and Stinson, 2015) and the wide ranging consequences of poor postural care have been summarised by the NHS Purchasing \& Supply Agency (2009). For the musculoskeletal system, these may include contractures, loss of joint integrity (e.g. hip dislocation), decreased bone density, reduced range of joint motion and deformity (e.g. spinal scoliosis). For the neurological system, these may include problems with spasticity/muscle tone, reflexes, altered sensation and joint position sense, pain, and weakness. Digestion may be affected, with swallowing and choking being compromised by poor head to neck posture. Additional areas where problems may arise include: respiratory function; kidney/renal function; personal hygiene, ease of toileting and changing; functional ability (e.g. weight bearing, transfer and hand function); environment interaction (sensory perception, body aesthetics, learning, communication); and sleep pattern and 
This is the authors' accepted version of a manuscript due to appear in a forthcoming issue of Journal of Applied Research in Intellectual Disabilities

irritability. Positioning and posture also underpin the ability to function and access the environment (Crawford and Stinson, 2015).

Over the past 15 years, there has been increased awareness of the need to provide postural care over the entire 24-hour period. This usually involves: adaptive seating and/or moulded wheelchairs; night time positioning equipment (NTPE); moving and handling techniques; and advice and training across all settings that the person accesses (Crawford and Stinson, 2015). NTPE can be used during the substantial proportion of the day when the person is in bed and has been reported to be beneficial even for those with established body shape distortion (Goldsmith, 2000).

It has been proposed that most people who lack the ability to change their position would benefit from 24-hour body positioning (Crawford and Stinson, 2015) and that 24-hour postural care strategies should be considered in physical therapy programmes to prevent or delay the development of contractures or skeletal deformities in children and young people at risk of developing these (National Institute for Health \& Care Excellence, 2012). However, disabled children generally are not being provided with the specialist equipment they require (such as seating and postural support systems), with provision of equipment being patchy at best (Centre for Economics and Business Research, 2014). It is widely accepted that the current systems that provide equipment and related services to children fail (CSED Consultant's Report, 2010).

The importance of the issue of postural care in relation to people with intellectual disabilities has been highlighted in a number of reports noting gaps in services and the need to provide postural care interventions to prevent postural deformities from developing (Michael, 2008, Mansell, 2010, RCGP, 2012, Heslop et al., 2013). Figures on how many people with intellectual disabilities require postural care are absent, although the number of people with profound and multiple learning disabilities (PMLD) can be used as an approximation. In 2014/15, 10,510 children in England had a Statement of Special Educational Needs (SEN) or an Education, Health and Care (EHC) Plan and were 
This is the authors' accepted version of a manuscript due to appear in a forthcoming issue of Journal of Applied Research in Intellectual Disabilities

identified as having a primary SEN associated with PMLD (Hatton et al., 2016). It has been estimated that in 2008, there were 16,036 adults with PMLD in England, with the numbers expected to rise by an average $1.8 \%$ annually to 2026 (Emerson, 2009).

No systematic reviews exist relating to postural care specifically for people with intellectual disabilities. Systematic reviews of systematic reviews point to limited evidence concerning postural care even when populations and interventions are broadly defined (Effgen and McEwen, 2008, Novak et al., 2013, Ryan, 2012). Systematic reviews, most commonly relating to people with cerebral palsy, have generally found insufficient high quality evidence for the effectiveness of a range of postural care interventions (Winfield et al., 2014, Bouwhuis et al., 2015, Legg et al., 2014, Katalinic et al., 2010, Prabhu et al., 2013, Kolman et al., 2015). However, limited evidence suggests that special-purpose adaptive seating systems may improve activities and participation for those with cerebral palsy (Gross Motor Functioning Classification System (GMFCS) IV and V) (Angsupaisal et al., 2015); there are indicative findings for an effect of bony surgery in stabilizing the hip in severe cerebral palsy (Bouwhuis et al., 2015); and hip surveillance involving standardised radiological screening of the hip even in children with no symptoms has been found to be effective in reducing hip dislocation in children with cerebral palsy (Novak et al., 2013, Gordon and Simkiss, 2006, Hägglund et al., 2014, Dobson et al., 2002).

For people with intellectual disabilities, the lack of evidence outlined above is compounded by issues that are likely to be more pertinent when providing postural care for this population. People with intellectual disabilities may have difficulties that make them less likely to be able to conform with a postural care programme. For example, NTPE is sometimes abandoned by users for a variety of reasons, such as difficulty sleeping (Hankinson and Morton, 2002), discomfort and temperature regulation, increased repositioning at night, and items being difficult to use and transport (Innocente, 2014). Sleep problems are common in adults and children with intellectual disabilities (c.f. van de Wouw et al., 2012, Priday et al., 2016) and likely to be a source of stress and sleep 
This is the authors' accepted version of a manuscript due to appear in a forthcoming issue of Journal of Applied Research in Intellectual Disabilities

deprivation for parents or carers. As such, the issue of abandonment due to sleep related issues may be more common in people with intellectual disabilities. Intellectual disabilities may also impact on the suitability of other postural care interventions, for example, cognitive impairment may reduce a patient's tolerance of bracing (Roberts and Tsirikos, 2016). Other issues raised in relation to intellectual disabilities include the need to address comfort in a specific adaptive seating system in children who also have severe communicative and cognitive impairments (Angsupaisal et al., 2015), and the need for studies of surgical interventions to assess pain expressed by the patients themselves especially for patients with intellectual disabilities (Boldingh et al., 2014).

In view of the issues outlined above, it cannot be assumed that research relating to people with cerebral palsy will apply equally to those with intellectual disabilities. In addition, whilst a proportion of participants in studies relating to cerebral palsy are likely to have an intellectual disability this information is rarely presented, and even allowing for a strong correlation between GMFCS level and intellectual functioning (Dalvand et al., 2012), it cannot be assumed that a child with a significant delay in motor function will also have an intellectual disability (Enkelaar et al., 2008). Conversely, only a minority (e.g. less than $25 \%$; Cans et al., 1999) of those with intellectual disabilities requiring postural care will have cerebral palsy. Indeed, a number of specific conditions related to intellectual disabilities may result in the need for postural care (Imagama et al., 2013, Burns et al., 2003, Detweiler et al., 2013, Damasceno et al., 2014, Li et al., 2015, Takebayashi et al., 2006, Ager et al., 2006, Karmaniolou et al., 2015, Kerr et al., 2003, Butler et al., 2002, Laurier et al., 2015, de Lind van Wijngaarden et al., 2008).

In summary, due to the potential impact of intellectual disabilities on the implementation of postural care programmes and the unique issues involved, it is important to clearly delineate research specifically relating to postural care for people with intellectual disabilities. This scoping review maps and summarises existing evidence to address the question of what the state of 
This is the authors' accepted version of a manuscript due to appear in a forthcoming issue of Journal of Applied Research in Intellectual Disabilities

evidence is with regards to postural care for people with intellectual disabilities, in order to identify gaps in the evidence base and provide a springboard for future research priorities.

\section{Methodology}

Scoping reviews are a relatively new methodology for which there is not yet a universal definition, definitive procedure or reporting guidelines (Pham et al., 2014). This scoping review employed an existing methodological framework (Arksey and O'Malley, 2005, Levac et al., 2010) which is the most frequently used scoping review methodology (Pham et al., 2014). It includes five stages: identifying the research question; identifying relevant studies; study selection; charting the data; collating, summarizing and reporting the results. As noted above, the research question was 'what is the state of evidence with regards to postural care for people with intellectual disabilities?'.

\section{Identifying Relevant Studies}

Electronic literature database searches were conducted in Medline, Cinahl and PsycINFO (all on EBSCO) and Web of Science (SCI-EXPANDED, SSCl and A\&HCI) covering January 1990 to March 2016. Searches combined word and index terms relating to postural care and intellectual disabilities with the Boolean operator 'and'. An initial list of search terms was sent to two experts in postural care for comment and all suggested additional terms included. An example of a database specific set of search terms (Medline) is given Appendix One. The reference lists of articles meeting the inclusion criteria were searched. In addition, in March 2016 an email request for information on research relevant to the review was sent to members of the International Association for the Scientific Study of Intellectual and Developmental Disabilities (IASSIDD) Health Special Interest Research Group and the Intellectual Disability UK Research mailing list.

\section{Study Selection}


This is the authors' accepted version of a manuscript due to appear in a forthcoming issue of Journal of Applied Research in Intellectual Disabilities

\section{Inclusion Criteria}

Articles were required to meet all the following criteria:

- Peer reviewed

- English Language full text

- Published from 1990 to March 2016

- Any research design

- Samples where $50 \%$ or more have intellectual disabilities or mixed samples where results are disaggregated for people with intellectual disabilities

- Presents results relating to postural care for people with intellectual disabilities who have severely impaired motor function.

\section{Exclusion Criteria}

- Reviews, letters, commentaries, editorials, meeting or conference abstracts

- Studies based on neonates (new born infants up to 28 days after birth)

- Studies on conditions where intellectual disabilities cannot be assumed (e.g. cerebral palsy) where results not disaggregated for people with intellectual disabilities

- In view of extremely specific issues related to postural care for people with relatively rare syndromes associated with intellectual disabilities (e.g. Williams-Beuren syndrome where mutation of the elastin gene leads to phenotypic changes in patients, including bone and joint dysfunctions (Damasceno et al., 2014)) studies relating only to people with relatively rare specific syndromes associated with intellectual disabilities were excluded (with the exception of Down syndrome which is the most common genetic cause of ID (Sherman et al., 2007)) 
This is the authors' accepted version of a manuscript due to appear in a forthcoming issue of Journal of Applied Research in Intellectual Disabilities

- Postural issues in those who are ambulatory e.g. gait, postural balance/falls, mobility programmes, sleep position in those who are ambulatory

- Micro switch technology unless specifically related to postural care

- Medical genetics

- Research on wheelchairs not specifically related to postural care (e.g. benefits of powered wheelchairs, interventions to facilitate independent wheelchair use)

- Surgery relating to primary conditions rather than posture per se e.g. hip replacement due to osteoarthritis

- Studies relating to scale development (e.g. Fife et al., 1991) unless relevant data available from the use of the scale

Initially, titles and abstracts were used to exclude articles obviously not within the scope of the review ( $1^{\text {st }}$ author). Those retained for further screening were those for which relevance could not be assessed without accessing the full text, or those that were potentially within scope. These studies were screened by two authors ( $1^{\text {st }}$ and last author) and discussed until consensus was reached on whether or not they met the inclusion criteria. All relevant studies were included in the review regardless of methodological quality.

In view of the sometimes unclear distinction between research relating to people with cerebral palsy and research relating to people with intellectual disabilities, a pragmatic approach was taken in that articles published in specialist intellectual disability journals were judged to be related to intellectual disabilities.

\section{Charting the data}

The following data were extracted by one reviewer and entered into an Excel spreadsheet: first author; year; country; study focus; method; sample source; key sample features; sample size; age 
This is the authors' accepted version of a manuscript due to appear in a forthcoming issue of Journal of Applied Research in Intellectual Disabilities

range (mean (SD); median); sample living situation; \% male; outcome measures (if applicable); and key findings. These data are summarised in Table 1.

Results were collated, summarised and reported via a descriptive numerical summary of included studies (e.g. number with particular research designs) and a thematic analysis (Levac et al., 2010). An iterative approach was taken in which a list of themes was identified via reading and re-reading the study summaries in Excel and these themes were allocated to overarching themes (Braun and Clarke, 2006). A descriptive narrative summary was used to present results.

\section{Results}

The process of identifying studies for inclusion is summarised in Fig. 1. Electronic database searches identified a total of 1,262 references (Medline 822, Cinahl 157, PsycINFO 192, AMED 91), with 1,026 remaining after removal of 236 duplicates. Following the first examination of articles, 149 remained for further consideration. After examination of full text articles and the addition of articles from other sources, 25 articles met the criteria for inclusion. These are summarised in Table 1. Each article presents information on a unique study, with the exception of one study which was described across two articles (Sewell et al., 2016, Sewell et al., 2015) and a further study also described across two articles (Neilson et al., 2000, Neilson et al., 2001), giving a total of 23 studies.

\section{Figure One Here}

\section{Geographical Spread}

Of the 23 studies, seven were conducted in the US, six in England, two in Scotland, one in England and Scotland and one in each of Australia, Canada, Germany, Italy, Japan, the Netherlands and Taiwan. 
This is the authors' accepted version of a manuscript due to appear in a forthcoming issue of Journal of Applied Research in Intellectual Disabilities

\section{Methodological Design}

The study designs included: retrospective cohort studies; single subject designs; cross-sectional surveys; within subjects quasi-experimental designs; case studies; case series; a mixed methods study consisting of an online survey and semi-structured interviews and focus groups; a qualitative focus group; a between subjects comparison of orthopaedic, functional, and cardiopulmonary measures in those who did and did not have scoliosis curves of $>45^{\circ}$; a retrospective review of surgery outcomes; and one study looking at postural alignment of patients and the relationship to 3D scans of the seating support surface.

Nine of the 23 studies had sample sizes of 10 or less. No study had a sample size of 100 or more.

Table 1 Here

\section{Themes}

In the following sections, we present a narrative summary of information identified in the 23 studies in relation to three themes (one study contributed to two themes): characteristics and prevalence of people with intellectual disabilities requiring postural care (4 studies); interventions (17 studies: surgery, behavioural, equipment, positioning and 'other'); and service related issues ( 3 studies).

Characteristics \& prevalence of people with intellectual disabilities requiring postural care

Four studies included some information relating to the characteristics (including progression of postural related ill health) of people with intellectual disabilities requiring postural care, and prevalence of conditions related to postural issues. No studies on the number of people with intellectual disabilities requiring postural care were found. A study of 55 non-ambulatory, institutionalized adults with profound intellectual disabilities found conditions including scoliosis 
This is the authors' accepted version of a manuscript due to appear in a forthcoming issue of Journal of Applied Research in Intellectual Disabilities

(severity undefined) in $34 / 55$ people (62\%), contractures ( $23 / 55$ people; $42 \%)$, and dislocation of hips (13/55 people; 24\%) (Kozma and Mason, 2003). A more recent study of 99 adults with severe or profound intellectual and profound motor disabilities gives the percentage of those with spasticity (76\%), deformations (72\%; scoliosis 56\%; hip 39\%), contracture (32\%), and decubitus/pressure area (20\%) (van Timmeren et al., 2016). A comparison of patients with untreated scoliosis $\left(>45^{\circ}\right)$ to those with mild or no curves found they had more orthopaedic deformities involving the pelvis and hips and were more likely to need modified wheelchairs (Kalen et al., 1992). The authors suggest that the lack of difference found (e.g. on cardiopulmonary measures) to those with mild or no curves suggests careful consideration should be made before recommending a major surgical procedure, although it is acknowledged that it would have been better to compare those who have/have not had surgery for scoliosis.

One case study is presented of a male for whom severe scoliosis contributed to premature death (Waugh and Hill, 2009). X-rays demonstrate progress from symmetrical body shape at age 3 to severe scoliosis at age 23 shortly prior to death. The internal capacity of the thorax and abdomen reduced such that the right lung ceased to function. Body shape distortion caused: pain and discomfort; pelvic obliquity and rotation; disintegration of hips; respiratory failure; movement of digestive organs into the space reserved for lungs; and arrested peristaltic movement leading to faecal impaction.

\section{Interventions}

Most commonly, various interventions relating to postural care have been the focus of studies and these are described below in the categories of: surgery (3 studies); behavioural approaches ( 3 studies); equipment (7 studies); and positioning (3 studies). In addition, one study found that some participants benefitted from reduced muscle tone during relaxation training (Hegarty and Last, 1997). 
This is the authors' accepted version of a manuscript due to appear in a forthcoming issue of Journal of Applied Research in Intellectual Disabilities

Surgery. Three studies considered the outcomes of surgery. An early retrospective review of older children undergoing proximal femoral resection (where the femoral head and a portion of the femur are removed) for subluxation (partial dislocation) or dislocation of the hip found mixed results, with poor clinical results noted to be continued pre-operative pelvic obliquity, postoperative adduction contracture, and bony contact between the pelvis and the remaining proximal femur or its heterotopic ossification (bone tissue formation outside of the skeleton) (Perlmutter et al., 1993). Of the 13 patients in the study, 6 had a continued need for pain medication and all of these continued to demonstrate bony contact either by heterotopic ossification or by continued proximal femoral impingement onto the pelvis. The authors suggest that prevention of hip dislocation by very early treatment yields a more predictable and positive long-term outcome than their reported cases involving older children.

More recent studies have considered surgery for scoliosis. A study on radiological and clinical results after surgical correction of scoliosis by posterior-only ( $\mathrm{P}$; from the back of the spine) or combined anterior-posterior instrumented fusion (AP; from the front and back of the spine) in 57 patients with cerebral palsy (GMFCS IV or V) found good results, with an overall Cobb angle (a standard measurement to determine and track the progression of scoliosis) correction of $52 \%$ ( $54 \%$ in group $P, 50 \%$ in group AP) (Beckmann et al., 2016). Major complications occurred in $23 \%$ (P) versus $46 \%$ (AP). Posterior instrumentation appeared to lead to comparable radiological results with shorter operations and shorter ICU and hospital stays than with combined surgery. However, a limitation was that preoperative pelvic obliquities differed between the two groups (group P $15^{\circ}$, group AP $26^{\circ}$ ). Preoperative deformities were severe (mean preoperative Cobb angle $94^{\circ}$ ) and the authors suggest that better results with fewer complications might be achieved if patients undergo surgery at an earlier stage.

One study considered the outcomes of spinal fusion for scoliosis in 34 children with cerebral palsy (GMFCS IV or V) in relation to activity and participation (Sewell et al., 2015) and carer assessed 
This is the authors' accepted version of a manuscript due to appear in a forthcoming issue of Journal of Applied Research in Intellectual Disabilities

quality of life (QoL) (Sewell et al., 2016). The study also compares outcomes to 36 younger children with significant scoliosis who did not undergo surgery and effectively had worsening scoliosis (as such, the groups were not strictly comparable). Spinal fusion was associated with an improvement in activity and participation and a decrease in spinal-related pain, whereas nonoperative treatment was associated with a small reduction in activity and participation and an increase in pain (Sewell et al., 2015). Spinal-related pain was the factor that correlated most with change in activity and participation in both groups. Similarly, spinal fusion was associated with an increase in QoL whereas nonoperative treatment was associated with a small decrease in carer-assessed QoL over 2 years (Sewell et al., 2016). Change in pain was the most significant factor affecting QoL changes. There was no difference in mobility, GMFCS level, feeding, or communication in either group.

Behavioural Approaches: Stimuli contingent on appropriate posture. Three studies with a total of seven participants used technology to provide stimuli contingent upon appropriate posture. In an early study, a switch activated by appropriate head and trunk position which turned on music was effective in increasing the duration of appropriate posture, although the average time in correct posture remained small (Domaracki et al., 1990). Similarly, one study adapted a Wii controller to turn on videos contingent on appropriate head posture and found that both participants significantly increased time spent with correct head posture (Shih et al., 2011). Finally, one study using pressure microswitches to establish choice responding prior to using stimuli (songs) contingent on appropriate head and trunk posture found that problem postures reduced to very low levels (Lancioni et al., 2015). It has been suggested that such methods could be used to maintain therapeutic posture without the need for constant one to one supervision thus extending 'therapy' time to a greater part of the day (Domaracki et al., 1990).

Equipment. Seven studies considered issues related to equipment. An early study looked at the effectiveness of a prototype seating harness for standard wheelchairs (Rennie and Flynn, 1992) with 10 adults. The prototype allowed significantly less movement than either a crutch strap or lap strap, 
This is the authors' accepted version of a manuscript due to appear in a forthcoming issue of Journal of Applied Research in Intellectual Disabilities

and all harnesses allowed less forward slide than when no harness was used. This was taken as an indication of the value of a harness, and the prototype harness in particular, in assisting the prevention of pressure sores and increasing disability resulting from poor posture.

A two phase study focused on the effects of a static versus a dynamic (motorized) prone stander on bone mineral density (phase I) and behaviour related to tasks and specific goals (phase II) in four preschool children with severe cerebral palsy (Gudjonsdottir and Stemmons Mercer, 2002). In phase I there were increases in bone mineral density in both children who used a dynamic stander and one of two children who used a static stander. In phase II there was little or no effect of type of stander on behaviour. It was noted that all tolerated the standing program well and often showed displeasure when the standing session was over.

One study looked at the relationship between postural head and neck alignment of patients and the configuration of the 'Seating Buggy' seating support surface measured using 3D scanning (Hatta et al., 2007). Seating was assessed as ill fitting in 10 out of the 21 participants. It was suggested that properly adjusted depth of thoracic support and distance of the lumbar support were related to satisfactory head-neck alignment and sitting balance.

One study looked at the impact of a malleable spinal brace (Soft Boston Orthosis) on measures of pulmonary mechanics (Leopando et al., 1999) with 12 young adults. Use of the orthosis did not significantly affect pulmonary mechanics or measurements of gas exchange. There was a trend toward increasing the work of breathing when the individuals were not wearing their orthoses, with the work of breathing being greatest in the sitting position without the orthosis. (It is noted that rigid braces can cause a decrease in vital capacity in young people with muscular dystrophy and scoliosis). 
This is the authors' accepted version of a manuscript due to appear in a forthcoming issue of Journal of Applied Research in Intellectual Disabilities

A survey matched the responses of 30 parents of a child with multiple and complex needs with those of the physiotherapist or occupational therapist involved in their seating in relation to perceptions of seating equipment (McDonald et al., 2007). Parents reported more 'dislikes' than therapists suggesting they had more experience of problems. Parents were particularly concerned with the ease of use and practical aspects of the seating system but this issue was not raised by therapists. Activity and participatory factors were not mentioned and the authors suggest that the child's activity, participation, environmental, and personal factors should be considered in addition to postural care when supplying children and their families with adaptive seating systems.

One study, which aimed to develop a model for evaluating the consequences of surgical and orthotic interventions for people with profound intellectual and multiple disabilities and their carers, reported benefits associated with moulded seats inserts for wheelchairs (Neilson et al., 2001). Whilst most of the 27 participants had used moulded inserts previously and received reconfigured inserts, patients benefited both physically and functionally with benefits in quality of life, sitting posture, feeding behaviour, and carer satisfaction with the results. Benefits in quality of life were less apparent for carers than for patients which may be because despite significant functional improvement, patients remained entirely dependent. When also including surgical and orthotic interventions, $62.5 \%$ of carers were satisfied with the wide ranging interventions (Neilson et al., 2000). Carers' satisfaction ratings in relation to 'posture' were 'good, very good or excellent' $(n=13)$ \& 'poor to fair' $(n=3)$.

Finally, one recent study based on 13 qualitative case studies considers the comfort of children and young people with intellectual disabilities who were unable to verbalise when using positioning equipment (adaptive seating, standers and sleep systems) (Lyons et al., 2016). Facial and vocal expressions were predominant for detecting discomfort/comfort in most participants but whether discomfort from equipment was present sometimes remained unclear. Threats to comfort included the restrictive nature of some equipment, stretch procedures and positioning errors. Parents were 
This is the authors' accepted version of a manuscript due to appear in a forthcoming issue of Journal of Applied Research in Intellectual Disabilities

generally supportive of professionals using the equipment to achieve both health and educationally related goals but they also wanted periods of relaxation for their children with time out of restrictive equipment.

Positioning. Three studies considered issues specifically related to positioning. A study on the effects of positioning (supine, sitting, sidelying) on respiratory measures found that whilst results differed depending on the participant and outcome variables, oxygen saturaton $\left(\mathrm{SaO}^{2}\right)$ was greater in sitting or sidelying than supine for $3 / 5$ participants (Littleton et al., 2011). It is acknowledged that further research with a larger sample is needed to empirically link specific positions with improved respiratory efficiency.

One study examined the effects of positioning (wheelchair, sidelying, and "freestyle" on a mat without assistive equipment) on social-communicative interactions (McEwen, 1992). During structured interactions, adults initiated communication more when the 10 participants were in their wheelchair (small to medium effect size). Position did not affect students' communication during unstructured observations. The lowest functioning students $(n=5)$ communicated more whilst in 'freestyle' (supine) during the structured observations (large effect size). The authors note that this latter finding was unexpected and further investigation is needed.

Finally, a case study of a girl with severe scoliosis who had been referred for surgery for rods in her spine is presented which illustrates pictorially scoliosis being improved and surgery being avoided following the adoption of night time positioning (Waugh and Hill, 2009).

\section{Service related issues}

One study looked at the views, understanding and training needs of members of a multidisciplinary team (MDT) who refer those with PMLD to 24-hour postural care (excluding physiotherapists who 
This is the authors' accepted version of a manuscript due to appear in a forthcoming issue of Journal of Applied Research in Intellectual Disabilities

provide 24-hour postural care) (Castle et al., 2014). Survey results indicated that around half of all the 57 MDT members who responded refer to the 24 -hour postural care service. The vast majority did not have a specific assessment tool for identifying the postural needs of patients. Very few had received any training about the role and benefits of 24-hour postural care and nearly a third said they had no knowledge about the meaning and benefits of 24-hour postural care. The majority said that they would be happy to receive more training on 24-hour postural care with most favouring group training that included a checklist or screening tool to help identify 24-hour postural care needs. Results of qualitative interviews and focus groups with smaller numbers of people indicate that MDT members were not able to identify why individuals should be referred to the 24-hour postural care service and participants were unanimous in agreeing the need for further training specific to 24-hour postural care. Participants identified training to be important as it provides insight into the rationale for referrals and the essential clinical skills for recognising potential postural problems of patients with PMLD.

A survey looked at teacher and therapist views on postural care in a special school setting (Maher et al., 2011). The majority of the 18 participating teachers thought one or two position change(s) per day was optimal and cited fewer benefits of postural care than the 43 participating therapists. Reported barriers included unavailability of appropriate positioning equipment, education staff lacking the time and/or skills to carry out the programme and insufficient communication between education and therapy staff. Integration of postural care into the daily routine, provision of a written programme from therapy staff and increased communication between therapy and education staff were cited as facilitators. Overall, it is suggested that teachers would benefit from training with regards to postural care.

One study looked at the views of 11 professionals and carers from paediatric or learning disability services who were involved in the development and/or implementation of an integrated care pathway (ICP) for 24-hour postural care (Humphreys and Pountney, 2006). Team members felt that 
This is the authors' accepted version of a manuscript due to appear in a forthcoming issue of Journal of Applied Research in Intellectual Disabilities

the ICP had the effect of making members' interventions proactive rather than reactive. A training package for all carers that was put in place had been a keystone of the ICP and provoked enthusiasm from all members of the team. The training of respite carers was of concern due to the need to implement postural care across a wide range of settings. Overall, the perception was that the ICP had improved service delivery and would improve outcomes for children and adults with motor impairment, as one participant noted: "It's going to make untold difference to the whole of their lives. It sounds sort of visionary but ..." (p237).

\section{Discussion}

Despite broad inclusion criteria, this review has identified only a small body of research relating to postural care for people with intellectual disabilities. Whilst a wide range of issues has been covered in the identified studies, few studies were found for each theme and overall sample sizes are small. Further, some studies have serious methodological limitations such as a lack of control of additional confounding factors which may have influenced outcomes. Overall, there were no RCTs or prospective studies.

There are significant gaps in the literature. Whilst there is some evidence to suggest that a substantial proportion of people with severe or profound intellectual disabilities are likely to have postural care needs, accurate data on this issue do not exist. Such data would be useful for those who need to plan services for this group.

Whilst this review has presented some small scale evidence regarding postural care interventions, of particular importance is the lack of evidence regarding NTPE and 24-hour postural care service provision. It has been suggested that effective 24-hour postural care can prevent deformity (Hill and Goldsmith, 2010, Crawford and Stinson, 2015) and thus avoid the negative health and quality of life implications associated with poor posture and avoid invasive interventions such as surgery for 
This is the authors' accepted version of a manuscript due to appear in a forthcoming issue of Journal of Applied Research in Intellectual Disabilities

scoliosis (Waugh and Hill, 2009) which is frequently associated with major complications (Beckmann et al., 2016). The lack of research evidence to support the efficacy of NTPE and 24-hour postural care needs to be addressed urgently, including a focus on the specific issues that may arise in relation to interventions involving people with intellectual disabilities.

There are a number of reasons for urgently addressing this gap in evidence. Firstly, a national survey of paediatric physiotherapists found that inability to obtain funding was the second most common reason cited for lack of access to NTPE despite potential benefit for an individual (NHS Purchasing \& Supply Agency, 2009, Polak and Clift, 2007). Securing funding was noted to be very time consuming and lack of robust clinical efficacy data can make the justification for funding problematic (NHS Purchasing \& Supply Agency, 2009). Indeed, in light of the lack of well-designed RCTs, the authors of a Cochrane review challenge the assumption that sleep positioning systems are a proven, effective treatment to reduce or prevent hip migration (Blake 2015). They also suggest that adverse effects appear underreported, perhaps because, in these instances, the equipment is usually abandoned.

There was a dearth of research on service related issues. Research is limited to studies on the perceptions of key stakeholders regarding postural care. No studies were found on how best to provide postural care services for this population. It is evident that across the UK, there are examples of innovations in practice that attempt to improve postural care for people with intellectual disabilities but peer reviewed research relating to these innovations is lacking. For example, in one area of England, a rise in critical incidents linked to poor postural care among patients living in supported living services was the impetus for developing a training package for all members of staff in the supported living service, leading to a tripling in referral rates (Mooney, 2014). Another area (Wakefield) has a clear postural care pathway, with referred children having a baseline measurement of postural symmetry, equipment being put in if needed and follow-up measurements being taken at least once a year (Snell, 2012). This approach, focused on early intervention and prevention, has been claimed to have cost benefits due to preventing the need for 
This is the authors' accepted version of a manuscript due to appear in a forthcoming issue of Journal of Applied Research in Intellectual Disabilities

surgical interventions. One area has set up two clinics to assess the posture of adults with profound and multiple learning disabilities, with regular reassessment and monitoring (Millett, 2015). A new occupational therapy 24-hour postural care service for people with learning disabilities in one city in the UK was evaluated after 12 months using a carer feedback questionnaire and found to have a positive impact on both clients and carers (Crawford and Curran, 2014). Finally, a one year postural care training programme for the workforce supporting the needs of children and young people with complex healthcare needs has also been described and evaluated (Hill, 2011). Closer links between researchers and those involved in such innovations in practice would help to build a more robust evidence base relating to postural care services.

Whilst the lack of evidence relating to people with intellectual disabilities partly reflects the lack of evidence regarding postural care for other populations, there are a number of additional potential reasons for the lack of robust research evidence concerning postural care for people with intellectual disabilities. First, people with intellectual disabilities are largely excluded from mainstream health and medical research (Feldman et al., 2013). Second, there are challenging ethical and logistical problems when conducting RCTs with people with intellectual disabilities (Oliver-Africano et al., 2010). Further, the population of people with intellectual disabilities who are likely to require postural care is a relatively small and scattered population across services where geographically there is no consistency in the provision (if any) of postural care services. Finally, behavioural issues may influence the participation of those with intellectual disabilities in studies of postural care. For example, it has been noted that assessment of pulmonary mechanics in individuals with severe cerebral palsy and marked cognitive impairment had never been reported, probably because of the difficulty of studying subjects who are unable to cooperate (Leopando et al., 1999). One study also excluded those with sensory defensiveness affecting tolerance for handling techniques (Littleton et al., 2011). 
This is the authors' accepted version of a manuscript due to appear in a forthcoming issue of Journal of Applied Research in Intellectual Disabilities

A further issue is the wide diversity of people with intellectual disabilities who may require postural care and the resultant diversity in needs. As noted in the introduction, there are varied specific syndromes associated with intellectual disability which may be associated with postural care needs and a limitation of this review is the exclusion of studies only relating to such syndromes. For example, in Prader-Willi syndrome (PWS), over two thirds of patients are affected by scoliosis at skeletal maturity (Odent et al., 2008), with scoliosis surgery frequently being necessary and associated with a high rate of complications (Accadbled et al., 2008). It has been suggested that in PWS, osteopenia, poor impulse control and defiant behaviours, and diminished pain sensitivity may complicate all aspects of orthopaedic nonsurgical and surgical management (Kroonen et al., 2006).

Similarly, as many as $40 \%$ of people with Rett syndrome have been reported to undergo corrective spinal surgery (Anderson et al., 2014) and children with Rett syndrome are very likely to undergo spinal fusion (Karmaniolou et al., 2015). Whilst positive outcomes of spinal surgery have been reported (Larsson et al., 2009, Downs et al., 2009, Kerr et al., 2003), it is associated with a high rate of postoperative major medical complications (Gabos et al., 2012). Further, for families of people with Rett syndrome, the decision to proceed with spinal fusion surgery can be associated with feelings of fear, obligation, relief and guilt (Marr et al., 2015). Little research has considered other aspects of postural care for people with Rett syndrome, with physiotherapy and bracing having been reported to be perceived as not reducing the progression of scoliosis (Ager et al., 2009). Future review work should consider the body of research on postural care for people with relatively rare syndromes associated with intellectual disabilities.

Recent research in the field of postural care has acknowledged the need to consider the degree of impairment of participants (Beckmann et al., 2016). Future research involving people with cerebral palsy should include information on the degree of intellectual impairment of participants in a standardized way. Future research should also address the question of whether early intervention could prevent or reduce asymmetry in people with intellectual disabilities. It is also unclear as to 
This is the authors' accepted version of a manuscript due to appear in a forthcoming issue of Journal of Applied Research in Intellectual Disabilities

what adjustments might need to be made to interventions for those with behavioural issues that limit their tolerance of postural care. Recent research has also gone beyond body structure to consider outcomes related to quality of life such as activity and participation (Sewell et al., 2016, Sewell et al., 2015). This is in line with the suggestion that focus in the use of postural care should consider the environment and participation in addition to body structure (Gough, 2009, McDonald et al., 2007).

\section{Conclusion}

The evidence base relating to postural care for people with intellectual disabilities and severely impaired motor function is small and lacking in studies that employ robust methodological designs. There are areas where there is a dearth of research which warrant urgent attention. Most notably, there is an urgent need for evidence relating to NTPE and 24-hour postural care. Further, despite examples of innovations in practice, there is no research on how best to provide postural care services for this population. Further research co-designed by families, postural care practitioners and academics is needed. Large scale survey work could identify the potential needs that exist for postural care and map the current picture of service provision relating to postural care for people with intellectual disabilities. Careful evaluation work, for example using realist evaluation (Wong et al., 2016), could investigate the impact on people and families of living in an area with a comprehensive postural care service versus areas without such a service. Longer-term cohort studies of young children with postural care needs could be employed to investigate the long-term impacts of early interventions. Health economic modelling could consider the costs and effectiveness of postural care as a whole, and also particular components of postural care. In view of the likely ethical problems of conducting RCTs in this area, quasi-experimental designs, and particularly natural experiments (Craig et al., 2012) may be more acceptable ethically. This might include implementation studies where the introduction of comprehensive postural care services is staggered. Research based on the suggestions above would begin to ascertain how best postural 
This is the authors' accepted version of a manuscript due to appear in a forthcoming issue of Journal of Applied Research in Intellectual Disabilities

care interventions can be employed to help improve the health and quality of life of people with intellectual disabilities.

\section{References}

Accadbled F., Odent T., Moine A., Chau E., Glorion C., Diene G. \& de Gauzy J. S. (2008) Complications of scoliosis surgery in Prader-Willi syndrome. Spine, 33, 394-401.

Ager S., Downs J., Fyfe S. \& Leonard H. (2009) Parental experiences of scoliosis management in Rett syndrome. Disability And Rehabilitation, 31, 1917-1924.

Ager S., Fyfe S., Christodoulou J., Jacoby P., Schmitt L. \& Leonard H. (2006) Predictors of scoliosis in Rett syndrome. Journal Of Child Neurology, 21, 809-813.

Anderson A., Wong K., Jacoby P., Downs J. \& Leonard H. (2014) Twenty years of surveillance in Rett syndrome: what does this tell us? Orphanet Journal Of Rare Diseases, 9, 87.

Angsupaisal M., Maathuis C. G. B. \& Hadders-Algra M. (2015) Adaptive seating systems in children with severe cerebral palsy across International Classification of Functioning, Disability and Health for Children and Youth version domains: a systematic review. Developmental Medicine \& Child Neurology, 57, 919-930.

Arksey H. \& O'Malley L. (2005) Scoping studies: towards a methodological framework. International Journal of Social Research Methodology, 8, 19-32.

Beckmann K., Lange T., Gosheger G., Bövingloh A. S., Borowski M., Bullmann V., Liljenqvist U. \& Schulte T. L. (2016) Surgical correction of scoliosis in patients with severe cerebral palsy. European Spine Journal, 25, 506-516.

Boldingh E. J., Bouwhuis C. B., Heijden Maessen H. C., Bos C. F. \& Lankhorst G. J. (2014) Palliative hip surgery in severe cerebral palsy: a systematic review. Journal of Pediatric Orthopaedics B, 23, 86-92. 
This is the authors' accepted version of a manuscript due to appear in a forthcoming issue of Journal of Applied Research in Intellectual Disabilities

Bouwhuis C. B., van der Heijden-Maessen H. C., Boldingh E. J. K., Bos C. F. A. \& Lankhorst G. J. (2015) Effectiveness of preventive and corrective surgical intervention on hip disorders in severe cerebral palsy: a systematic review. Disability \& Rehabilitation, 37, 97-105.

Braun V. \& Clarke V. (2006) Using thematic analysis in psychology. Qualitative Research in Psychology, 3, 77-101.

Burns C., Powell B. R., Hsia Y. E. \& Reinker K. (2003) Dyggve-Melchior-Clausen syndrome: report of seven patients with the Smith-McCort variant and review of the literature. Journal Of Pediatric Orthopedics, 23, 88-93.

Butler J. V., Whittington J. E., Holland A. J., Boer H., Clarke D. \& Webb T. (2002) Prevalence of, and risk factors for, physical ill-health in people with Prader-Willi syndrome: a population-based study. Developmental Medicine And Child Neurology, 44, 248-255.

Cans C., Wilhelm L., Baille M. F., du Mazaubrun C., Grandjean H. \& Rumeau-Rouquette C. (1999) Aetiological findings and associated factors in children with severe mental retardation. Developmental Medicine \& Child Neurology, 41, 233-239.

Castle D., Stubbs B., Clayton S., Soundy A. \& Williams G. (2014) A 24-hour postural care service: Views, understanding and training needs of referring multidisciplinary staff. International Journal of Therapy \& Rehabilitation, 21, 132-139.

Centre for Economics and Business Research (2014) The economic benefits of better provision of equipment for disabled and terminally ill children: Report for the British Healthcare Trades Association,. Available online at: http://www.bhta.net/sites/default/files/documentupload/BHTA\%20paper\%20\%20benefits\%20of\%20better\%20provision\%20of\%20childrens\%27\%20equipment.pdf (accessed 5 July 2016).

Craig P., Cooper C., Gunnell D., Haw S., Lawson K., Macintyre S., Ogilvie D., Petticrew M., Reeves B., Sutton M. \& Thompson S. (2012) Using natural experiments to evaluate population health 
This is the authors' accepted version of a manuscript due to appear in a forthcoming issue of Journal of Applied Research in Intellectual Disabilities

interventions: new Medical Research Council guidance. Journal of Epidemiology and Community Health, 66, 1182.

Crawford S. \& Curran A. (2014) 24 hour postural management for community dwelling adults with learning disabilities. Posture \& Mobility: The Journal of the Posture \& Mobility Group, 31, 1519.

Crawford S. \& Stinson M. (2015) Management of 24hr-Body Positioning. In: International Handbook of Occupational Therapy Interventions. (Ed. Söderback, I). pp. 189-203. Springer.

CSED Consultant's Report (2010) Models and Options for Children's Equipment and Related Services. Available online at: http://www.communityequipment.org.uk/wp-content/uploads/DHreport-on-Childrens-equipment.doc (accessed 5 July 2016).

Dalvand H., Dehghan L., Hadian M. R., Feizy A. \& Hosseini S. A. (2012) Relationship Between Gross Motor and Intellectual Function in Children With Cerebral Palsy: A Cross-Sectional Study. Archives of Physical Medicine \& Rehabilitation, 93, 480-484.

Damasceno M. L., Cristante A. F., Marcon R. M. \& Barros Filho T. E. P. d. (2014) Prevalence of scoliosis in Williams-Beuren syndrome patients treated at a regional reference center. Clinics (São Paulo, Brazil), 69, 452-456.

de Lind van Wijngaarden R. F. A., de Klerk L. W. L., Festen D. A. M. \& Hokken-Koelega A. C. S. (2008) Scoliosis in Prader-Willi syndrome: prevalence, effects of age, gender, body mass index, lean body mass and genotype. Archives Of Disease In Childhood, 93, 1012-1016.

Detweiler S., Thacker M. M., Hopkins E., Conway L. \& Gripp K. W. (2013) Orthopedic manifestations and implications for individuals with Costello syndrome. American Journal Of Medical Genetics Part A, 161A, 1940-1949.

Dobson F., Boyd R. N., Parrott J., Nattrass G. R. \& Graham H. K. (2002) Hip surveillance in children with cerebral palsy. Impact on the surgical management of spastic hip disease. Journal of Bone \& Joint Surgery (Br), 84, 720-726. 
This is the authors' accepted version of a manuscript due to appear in a forthcoming issue of Journal of Applied Research in Intellectual Disabilities

Domaracki L. S., Sisson L. A., Robinson-Dassel K., Hamilton D. W. \& Goldstone F. (1990) Evaluation of biofeedback for improving head and trunk position in children with multiple, severe disabilities. Pediatric Physical Therapy, 2, 192-195.

Downs J., Young D., de Klerk N., Bebbington A., Baikie G. \& Leonard H. (2009) Impact of scoliosis surgery on activities of daily living in females with Rett syndrome. Journal Of Pediatric Orthopedics, 29, 369-374.

Effgen S. K. \& McEwen I. R. (2008) Review of selected physical therapy interventions for school age children with disabilities. Physical Therapy Reviews, 13, 297-312.

Emerson E. (2009) Estimating future numbers of adults with profound multiple learning disabilities in England. Centre for Disability Research, Lancaster University, Lancaster.

Enkelaar L., Ketelaar M. \& Gorter J. W. (2008) Association between motor and mental functioning in toddlers with cerebral palsy. Developmental Neurorehabilitation, 11, 276-282.

Feldman M. A., Bosett J., Collet C. \& Burnham-Riosa P. (2013) Where are persons with intellectual disabilities in medical research? A survey of published clinical trials. Journal of Intellectual Disability Research, 58, 800-809.

Fife S. E., Roxborough L. A., Armstrong R. W., Harris S. R., Gregson J. L. \& Field D. (1991) Development of a clinical measure of postural control for assessment of adaptive seating in children with neuromotor disabilities. Physical Therapy, 71, 981-993.

Gabos P. G., Inan M., Thacker M. \& Borkhu B. (2012) Spinal fusion for scoliosis in Rett syndrome with an emphasis on early postoperative complications. Spine, 37, E90-E94.

Gericke T. (2006) Postural management for children with cerebral palsy: consensus statement. Developmental Medicine \& Child Neurology, 48, 244.

Goldsmith E., Golding R. M., Garstang R. A. \& MacRae A. W. (1992) A Technique to Measure Windswept Deformity. Physiotherapy, 78, 235-242. 
This is the authors' accepted version of a manuscript due to appear in a forthcoming issue of Journal of Applied Research in Intellectual Disabilities

Goldsmith J. \& Goldsmith E. (2013) Goldsmith Indices of Body Symmetry Procedure Simple Stuff Works, Available online at: http://www.simplestuffworks.co.uk/downloads (accessed 24 March 2016).

Goldsmith S. (2000) The Mansfield Project: Postural Care at Night within a Community Setting: A Feedback Study. Physiotherapy, 86, 528-534.

Gordon G. S. \& Simkiss D. E. (2006) A systematic review of the evidence for hip surveillance in children with cerebral palsy. Journal of Bone \& Joint Surgery (Br), 88, 1492-1496.

Gough M. (2009) Continuous postural management and the prevention of deformity in children with cerebral palsy: an appraisal. Developmental Medicine \& Child Neurology, 51, 105-110.

Gudjonsdottir B. \& Stemmons Mercer V. (2002) Effects of a Dynamic Versus a Static Prone Stander on Bone Mineral Density and Behavior in Four Children with Severe Cerebral Palsy. Pediatric Physical Therapy, 14, 38-46.

Hägglund G., Alriksson-Schmidt A., Lauge-Pedersen H., Rodby-Bousquet E., Wagner P. \& Westbom L. (2014) Prevention of dislocation of the hip in children with cerebral palsy: 20-year results of a population-based prevention programme. Bone \& Joint Journal, 96-B, 1546-1552.

Hankinson J. \& Morton R. E. (2002) Use of a lying hip abduction system in children with bilateral cerebral palsy: a pilot study. Developmental Medicine \& Child Neurology, 44, 177-180.

Hatta T., Nishimura S., Inoue K., Yamanaka M., Maki M., Kobayashi N., Kishigami H. \& Sato M. (2007) Evaluating the relationships between the postural adaptation of patients with profound cerebral palsy and the configuration of the Seating Buggy's seating support surface. Journal Of Physiological Anthropology, 26, 217-224.

Hatton C., Emerson E., Glover G. \& Brown I. (2016) People with Learning Disabilities in England 2015. Public Health England, London.

Hegarty J. R. \& Last A. (1997) Relaxation training for people who have severe/profound and multiple learning disabilities. British Journal of Developmental Disabilities, 43, 122-139. 
This is the authors' accepted version of a manuscript due to appear in a forthcoming issue of Journal of Applied Research in Intellectual Disabilities

Heslop P., Blair P., Fleming P., Hoghton M., Marriott A. \& Russ L. (2013) The Confidential Inquiry into premature deaths of people with learning disabilities (CIPOLD): Final report. Norah Fry Research Centre, Bristol.

Hill S. (2011) A One Year Postural Care Training Programme for the Workforce Supporting the Needs of those with Complex and Continuing Healthcare Needs: Project Evaluation. Postural Care CIC \& Skills for Health.

Hill S. \& Goldsmith J. (2010) Biomechanics and prevention of body shape distortion. Tizard Learning Disability Review, 15, 15-32.

Humphreys G. \& Pountney T. (2006) The development and implementation of an integrated care pathway for 24-hour postural management: a study of the views of staff and carers. Physiotherapy, 92, 233-239.

Imagama S., Tsuji T., Ohara T., Katayama Y., Goto M., Ishiguro N. \& Kawakami N. (2013) Surgical treatment for kyphoscoliosis in Cohen syndrome. Nagoya Journal Of Medical Science, 75, 279-286.

Innocente R. (2014) Night time positioning equipment: A review of practices. New Zealand Journal of Occupational Therapy, 61, 13-19.

Kalen V., Conklin M. M. \& Sherman F. C. (1992) Untreated scoliosis in severe cerebral palsy. Journal Of Pediatric Orthopedics, 12, 337-340.

Karmaniolou I., Krishnan R., Galtrey E., Cleland S. \& Vijayaraghavan R. (2015) Perioperative management and outcome of patients with Rett syndrome undergoing scoliosis surgery: a retrospective review. Journal Of Anesthesia, 29, 492-498.

Katalinic O. M., Harvey L. A., Herbert R. D., Moseley A. M., Lannin N. A. \& Schurr K. (2010) Stretch for the treatment and prevention of contractures. Cochrane Database of Systematic Reviews, Issue 9. Art. No.: CD007455. DOI: 10.1002/14651858.CD007455.pub2.

Kerr A. M., Webb P., Prescott R. J. \& Milne Y. (2003) Results of surgery for scoliosis in Rett syndrome. Journal Of Child Neurology, 18, 703-708. 
This is the authors' accepted version of a manuscript due to appear in a forthcoming issue of Journal of Applied Research in Intellectual Disabilities

Kolman S. E., Ruzbarsky J. J., Spiegel D. A. \& Baldwin K. D. (2015) Salvage Options in the Cerebral Palsy Hip: A Systematic Review. Journal Of Pediatric Orthopedics, 36, 645-50.

Kozma C. \& Mason S. (2003) Survey of nursing and medical profile prior to deinstitutionalization of a population with profound mental retardation. Clinical Nursing Research, 12, 8-22.

Kroonen L. T., Herman M., Pizzutillo P. D. \& Macewen G. D. (2006) Prader-Willi Syndrome: clinical concerns for the orthopaedic surgeon. Journal Of Pediatric Orthopedics, 26, 673-679.

Lancioni G. E., Singh N. N., O’Reilly M. F., Sigafoos J., Perilli V., Campodonico F., Marchiani P. \& Lang R. (2015) Persons With Multiple Disabilities Engage in Stimulus Choice and Postural Control With the Support of a Technology-Aided Program. Behavior Modification, 39, 454-471.

Larsson E.-L., Aaro S., Ahlinder P., Normelli H., Tropp H. \& Oberg B. (2009) Long-term follow-up of functioning after spinal surgery in patients with Rett syndrome. European Spine Journal, 18, 506-511.

Laurier V., Lapeyrade A., Copet P., Demeer G., Silvie M., Bieth E., Coupaye M., Poitou C., Lorenzini F., Labrousse F., Molinas C., Tauber M., Thuilleaux D. \& Jauregi J. (2015) Medical, psychological and social features in a large cohort of adults with Prader-Willi syndrome: experience from a dedicated centre in France. Journal of Intellectual Disability Research, 59, 411-421.

Legg J., Davies E., Raich A. L., Dettori J. R. \& Sherry N. (2014) Surgical correction of scoliosis in children with spastic quadriplegia: benefits, adverse effects, and patient selection. EvidenceBased Spine-Care Journal, 5, 38-51.

Leopando M. T., Moussavi Z., Holbrow J., Chernick V., Pasterkamp H. \& Rempel G. (1999) Effect of a Soft Boston Orthosis on pulmonary mechanics in severe cerebral palsy. Pediatric Pulmonology, 28, 53-58.

Levac D., Colquhoun H. \& O'Brien K. K. (2010) Scoping studies: advancing the methodology. Implementation Science, 5, 1-9.

Li Z., Shen J., Liang J. \& Sheng L. (2015) Congenital scoliosis in Smith-Magenis syndrome: a case report and review of the literature. Medicine, 94, e705-e705. 
This is the authors' accepted version of a manuscript due to appear in a forthcoming issue of Journal of Applied Research in Intellectual Disabilities

Littleton S. R., Heriza C. B., Mullens P. A., Moerchen V. A. \& Bjornson K. (2011) Effects of positioning on respiratory measures in individuals with cerebral palsy and severe scoliosis. Pediatric Physical Therapy, 23, 159-169.

Lyons E. A., Jones D. E., Swallow V. M. \& Chandler C. (2016) An Exploration of Comfort and Discomfort Amongst Children and Young People with Intellectual Disabilities Who Depend on Postural Management Equipment. Journal of Applied Research in Intellectual Disabilities, Online early http://dx.doi.org/10.1111/jar.12267.

Maher C. A., Evans K. A., Sprod J. A. \& Bostock S. M. (2011) Factors influencing postural management for children with cerebral palsy in the special school setting. Disability And Rehabilitation, $33,146-158$.

Mansell J. (2010) Raising our sights: services for adults with profound intellectual and multiple disabilities. Department of Health, London.

Marr C., Leonard H., Torode I. \& Downs J. (2015) Spinal fusion in girls with Rett syndrome: postoperative recovery and family experiences. Child: Care, Health \& Development, 41, 10001009.

McDonald R. L., Surtees R. \& Wirz S. (2007) A comparative exploration of the thoughts of parents and therapists regarding seating equipment for children with multiple and complex needs. Disability and Rehabilitation: Assistive Technology, 2, 319-325.

McEwen I. R. (1992) Assistive positioning as a control parameter of social-communicative interactions between students with profound multiple disabilities and classroom staff. Physical Therapy, 72, 634-647.

Michael J. (2008) Healthcare for all: report of the independent inquiry into access to healthcare for people with learning disabilities. Department of Health, London.

Millett R. (2015) Postural care: Body work. Frontline Magazine: Chartered Society of Physiotherapy, $21,28$.

Mooney H. (2014) Pole position. Frontline Magazine: Chartered Society of Physiotherapy, 20, 34-36 
This is the authors' accepted version of a manuscript due to appear in a forthcoming issue of Journal of Applied Research in Intellectual Disabilities

National Institute for Health \& Care Excellence (2012) Spasticity in under 19s: management (clinical guideline 145). Available online at: https://www.nice.org.uk/guidance/cg145/chapter/1Guidance\# (accessed 5 July 2016).

Neilson A., Hogg J., Malek M. \& Rowley D. (2000) Impact of surgical and orthotic intervention on the quality of life of people with profound intellectual and multiple disabilities and their carers. Journal of Applied Research in Intellectual Disabilities, 13, 216-238.

Neilson A. R., Bardsley G. I., Rowley D. L., Hogg J., Malek M., Morrison G. C. \& Kirkwood C. A. (2001) Measuring the effects of seating on people with profound and multiple disabilities - a preliminary study. Journal Of Rehabilitation Research And Development, 38, 201-214.

NHS Purchasing \& Supply Agency (2009) Buyers Guide: night time postural management equipment for children. Centre for Evidence-based Purchasing, London.

Novak I., McIntyre S., Morgan C., Campbell L., Dark L., Morton N., Stumbles E., Wilson S.-A. \& Goldsmith S. (2013) A systematic review of interventions for children with cerebral palsy: state of the evidence. Developmental Medicine \& Child Neurology, 55, 885-910.

Odent T., Accadbled F., Koureas G., Cournot M., Moine A., Diene G., Molinas C., Pinto G., Tauber M., Gomes B., de Gauzy J. S. \& Glorion C. (2008) Scoliosis in patients with Prader-Willi Syndrome. Pediatrics, 122, e499-e503.

Oliver-Africano P., S. Dickens S., Ahmed Z., Bouras N., Cooray S., Deb S., Knapp M., Hare M., Meade M., Reece B., Bhaumik S., Harley D., Piachaud J., Regan A., AdeThomas D., Karatela S., Rao B., Dzendrowskyj T., Lenôtre L., Watson J. \& Tyrer P. (2010) Overcoming the barriers experienced in conducting a medication trial in adults with aggressive challenging behaviour and intellectual disabilities. Journal of Intellectual Disability Research, 54, 17-25.

Perlmutter M. N., Synder M., Miller F. \& Bisbal R. (1993) Proximal femoral resection for older children with spastic hip disease. Developmental Medicine And Child Neurology, 35, 525-531. 
This is the authors' accepted version of a manuscript due to appear in a forthcoming issue of Journal of Applied Research in Intellectual Disabilities

Pham M. T., Rajić A., Greig J. D., Sargeant J. M., Papadopoulos A. \& McEwen S. A. (2014) A scoping review of scoping reviews: advancing the approach and enhancing the consistency. Research Synthesis Methods, 5, 371-385.

Polak F. \& Clift M. (2007) The use of night time postural management equipment: a survey of UK paediatric chartered physiotherapists. Challenges for Assistive Technology, 20, 458-464.

Prabhu R. K. R., Swaminathan N. \& Harvey L. A. (2013) Passive movements for the treatment and prevention of contractures. Cochrane Database of Systematic Reviews, Issue 12. Art. No.: CD009331. DOI: 10.1002/14651858.CD009331.pub2.

Priday L. J., Byrne C. \& Totsika V. (2016) Behavioural interventions for sleep problems in people with an intellectual disability: a systematic review and meta-analysis of single case and group studies. Journal of Intellectual Disability Research, Online Early: doi: 10.1111/jir.12265

RCGP (2012) Improving the Health and Wellbeing of People with Learning Disabilities: An EvidenceBased Commissioning Guide for Clinical Commissioning Groups (CCGs) (Revised 2013). IHaL, RCGP \& RCPsych. Available online at:

http://www.improvinghealthandlives.org.uk/gsf.php5?f=17915\&fv=19233 (accessed 8 March 2016).

Rennie J. \& Flynn M. (1992) A prototype seating harness for people with a severe learning disability and physical handicap: an evaluation of effectiveness. Physiotherapy, 78, 740-744.

Roberts S. B. \& Tsirikos A. I. (2016) Factors influencing the evaluation and management of neuromuscular scoliosis: A review of the literature. Journal Of Back And Musculoskeletal Rehabilitation, Preprint, 1-11.

Ryan S. E. (2012) An overview of systematic reviews of adaptive seating interventions for children with cerebral palsy: where do we go from here? Disability and Rehabilitation: Assistive Technology, 7, 104-111.

Sewell M. D., Malagelada F., Wallace C., Gibson A., Noordeen H., Tucker S., Molloy S. \& Lehovsky J. (2016) A Preliminary Study to Assess Whether Spinal Fusion for Scoliosis Improves Carer- 
This is the authors' accepted version of a manuscript due to appear in a forthcoming issue of Journal of Applied Research in Intellectual Disabilities

assessed Quality of Life for Children With GMFCS Level IV or V Cerebral Palsy. Journal Of Pediatric Orthopedics, 36, 299-304.

Sewell M. D., Wallace C., Malagelada F., Gibson A., Noordeen H., Tucker S., Molloy S. \& Lehovsky J. (2015) Does Spinal Fusion and Scoliosis Correction Improve Activity and Participation for Children With GMFCS level 4 and 5 Cerebral Palsy? Medicine, 94, e1907.

Sherman S. L., Allen E. G., Bean L. H. \& Freeman S. B. (2007) Epidemiology of Down syndrome. Mental Retardation and Developmental Disabilities Research Reviews, 13, 221-227.

Shih C.-H., Shih C.-J. \& Shih C.-T. (2011) Assisting people with multiple disabilities by actively keeping the head in an upright position with a Nintendo Wii Remote Controller through the control of an environmental stimulation. Research In Developmental Disabilities, 32, 2005-2010.

Snell J. (2012) Learning curve. Frontline Magazine: Chartered Society of Physiotherapy, 18, 32-34.

Takebayashi T., Obata H., Minaki Y., Sekine M., Imoto K., Yokogushi K. \& Yamashita T. (2006) Scoliosis in cat cry syndrome. Journal Of Orthopaedic Science, 11, 259-263.

van de Wouw E., Evenhuis H. M. \& Echteld M. A. (2012) Prevalence, associated factors and treatment of sleep problems in adults with intellectual disability: A systematic review. Research in Developmental Disabilities, 33, 1310-1332.

van Timmeren E. A., van der Putten A. A. J., van Schrojenstein Lantman-de Valk H. M. J., van der Schans C. P. \& Waninge A. (2016) Prevalence of reported physical health problems in people with severe or profound intellectual and motor disabilities: a cross-sectional study of medical records and care plans. Journal of Intellectual Disability Research, Online Early: DOI: 10.1111/jir.12298.

Waugh A. \& Hill S. (2009) Body shape distortion: promoting postural care at night. Learning Disability Practice, 12, 25-29.

Winfield N., R., Barker N., J., Turner E., R. \& Quin G., L. (2014) Non-pharmaceutical management of respiratory morbidity in children with severe global developmental delay. Cochrane 
This is the authors' accepted version of a manuscript due to appear in a forthcoming issue of Journal of Applied Research in Intellectual Disabilities

Database of Systematic Reviews, Issue 10. Art. No.: CD010382. DOI:

10.1002/14651858.CD010382.pub2.

Wong G., Westhorp G., Manzano A., Greenhalgh J., Jagosh J. \& Greenhalgh T. (2016) RAMESES II reporting standards for realist evaluations. BMC Medicine, 14, 96. 
This is the authors' accepted version of a manuscript due to appear in a forthcoming issue of Journal of Applied Research in Intellectual Disabilities

\section{Appendix One: Example of database specific search terms (Medline)}

TI (postur* N1 (care or manag* or support)) OR AB (postur* N1 (care or manag* or support)) OR TI ("body shape") OR AB ("body shape") OR TI (positioning) OR AB (positioning) OR TI ("Iying posture") OR AB ("lying posture") OR TI ("adapt* seating") OR AB ("adapt* seating") OR TI ("supportive seating") OR AB ("supportive seating") OR TI ("seating system") OR AB ("seating system") OR TI ("sleep system") OR AB ("sleep system") OR TI ("therapeutic support") OR AB ("therapeutic support") OR TI ("night ortho*") OR AB (“night ortho*") OR TI ("chest distortion") OR AB ("chest distortion") OR TI (hip N2 (dislocation OR migration OR subluxation OR dysplasia)) OR AB (hip N2 (dislocation OR migration OR subluxation OR dysplasia)) OR TI (scoliosis) OR AB (scoliosis) OR TI ("respiratory function") OR AB ("respiratory function") OR TI (contracture) OR AB (contracture) TI ("standing frame") OR AB ("standing frame") OR TI (stander) OR AB (stander) OR TI (wheelchair) OR AB (wheelchair) OR TI (“hip surveillance") OR AB (“hip surveillance”) OR (MM

"Scoliosis/TH/SU/EP/NU/RH") OR (MM “Posture") OR (MM "Patient positioning") OR (MM "Wheelchairs") OR (MM “hip dislocation") OR (MM “Orthotic devices")

AND

TI ( learning N1 (disab* or difficult* or handicap*) ) OR TI ( mental* N1 (retard* or disab* or deficien* or handicap*) ) OR TI ( intellectual* N1 (disab* or impair* or handicap*) ) OR TI (development* N1 disab*) OR TI ( multipl* N1 (handicap* or disab*) ) OR TI (profound* N2 (disab* OR handicap*)) OR AB (profound* N2 (disab* OR handicap*)) OR TI ("intellectual function*”) OR AB (“intellectual function*”) OR TI ("Down* syndrome") OR TI ("intellectual development disorder") OR AB ("intellectual development disorder") OR ( $M H$ "Developmental Disabilities") OR (MH "Intellectual Disability+") OR (MH "mentally disabled persons") OR AB ( learning N1 (disab* or difficult* or handicap*) ) OR AB ( mental* N1 (retard* or disab* or deficien* or handicap*) ) OR AB ( intellectual* 
This is the authors' accepted version of a manuscript due to appear in a forthcoming issue of Journal of Applied Research in Intellectual Disabilities

N1 (disab* or impair* or handicap*) ) OR AB (development* N1 disab*) OR AB ( multipl* N1 (handicap* or disab*) ) OR AB ("Down* syndrome")

Limiters: from 1990; English Language. 
Table 1: Summary of studies relating to postural care for people with intellectual disabilities

\begin{tabular}{|c|c|c|c|c|c|c|c|c|c|}
\hline Theme $^{1}$ & $\begin{array}{l}\text { First author \& } \\
\text { year }\end{array}$ & Country & Study Focus & Study design & Key sample features & $\begin{array}{l}\text { Sample } \\
\text { size }\end{array}$ & $\begin{array}{l}\text { Age range } \\
\text { (mean (SD); } \\
\text { median) yrs }\end{array}$ & $\begin{array}{l}\% \\
\text { male }\end{array}$ & Key Findings \\
\hline I (S) & \begin{tabular}{|l} 
Beckman \\
2016
\end{tabular} & Germany & $\begin{array}{l}\text { Radiological \& clinical } \\
\text { results after posterior-only } \\
\text { (P) or combined anterior- } \\
\text { posterior instrumented } \\
\text { fusion (AP) for correction of } \\
\text { scoliosis }\end{array}$ & $\begin{array}{l}\text { Retrospective } \\
\text { cohort study }\end{array}$ & $\begin{array}{l}\text { Severe CP (GMFCS IV or V). } \\
\text { Moderate to severe ID: P } 33 / 35(94 \%) \\
\text { AP 16/22 (73\%) }\end{array}$ & $\begin{array}{l}\text { P 35; } \\
\text { AP 22 }\end{array}$ & $\begin{array}{l}\text { P ns }(15(4) ; \\
\text { ns); } \\
\text { AP ns (16.5 } \\
(7) ; n s)\end{array}$ & $\begin{array}{l}\text { A } \\
46 \% \\
\text { AP } \\
50 \%\end{array}$ & $\begin{array}{l}\text { Preoperative deformities severe with mean Cobb angle } 94^{\circ} \text {. Results } \\
\text { good, with overall Cobb correction of } 52 \% \text { ( } 54 \% \text { P, } 50 \% \text { AP). Major } \\
\text { complications in } 23 \% \text { (P) vs } 46 \% \text { (AP). AP group had longer } \\
\text { operations, greater blood loss \& longer hospital stays \& ICU stays. } \\
\text { Correction of the main curve was similar at discharge }(54 \% \text { P, } 50 \% \text { AP) }\end{array}$ \\
\hline$S$ & \begin{tabular}{|l|} 
Castle 2014 \\
Phase I
\end{tabular} & England & $\begin{array}{l}\text { Views, understanding \& } \\
\text { training needs of members } \\
\text { of a multidisciplinary team } \\
\text { (MDT) }\end{array}$ & $\begin{array}{l}\text { Mixed } \\
\text { methods } \\
\text { Phase I: } \\
\text { online survey }\end{array}$ & $\begin{array}{l}\text { MDT members who may refer people } \\
\text { with PMLD to the LD physiotherapy } \\
\text { service for } 24 \text {-hr postural care. }\end{array}$ & 57 & $\begin{array}{l}20-65 \text { (ns } \\
\text { (ns); ns). } 42 \\
\text { aged } 36-55\end{array}$ & $77 \%$ & $\begin{array}{l}50 \% \text { refer to the } 24 \text {-hour postural care service. The majority felt they } \\
\text { had no ( } 30.4 \%) \text { or some }(53.6 \%) \text { knowledge about the meaning \& } \\
\text { benefits of } 24 \text {-hour postural care. } 82.5 \% \text { did not have a specific } \\
\text { assessment tool for identifying the postural needs of patients. } 54.4 \% \\
\text { were not happy with the amount of training in } 24 \text {-hour postural care they } \\
\text { received \& } 75.4 \% \text { said they would be happy to receive more training. } \\
5.4 \% \text { of respondents had received any training about the role \& benefits } \\
\text { of } 24 \text {-hour postural care, while } 78.9 \% \text { believed this would benefit } \\
\text { patients with PMLD. } 68.4 \% \text { favoured group training that included a } \\
\text { checklist or screening tool to help identify } 24 \text {-hour postural care needs }\end{array}$ \\
\hline I (B) & $\begin{array}{l}\text { Domaracki } \\
1990\end{array}$ & US & $\begin{array}{l}\text { Effectiveness of } \\
\text { biofeedback for improving } \\
\text { head \& trunk position }\end{array}$ & $\begin{array}{l}\text { Single subject } \\
\text { design }\end{array}$ & $\begin{array}{l}\text { Children with severe to profound ID \& } \\
\text { multiple disabilities including visual } \\
\text { impairment \& problems with posture } \\
\text { control }\end{array}$ & 2 & $6 \& 8$ & $50 \%$ & $\begin{array}{l}\text { Biofeedback (music) was effective in increasing the duration of } \\
\text { appropriate posture. Average time in correct posture remained small } \\
\text { even with intervention. }\end{array}$ \\
\hline \multirow[t]{2}{*}{$I(E)$} & $\begin{array}{l}\text { Gudjonsdottir } \\
2002 \\
\text { Phase I }\end{array}$ & US & $\begin{array}{l}\text { Effects of a dynamic versus } \\
\text { a static prone stander on } \\
\text { bone mineral density (BMD) }\end{array}$ & Case series & $\begin{array}{l}\text { Preschool children with severe CP \& } \\
\text { functioning below developmental age of } \\
9 \text { months, } 2 \text { with no mobility, } 2 \text { able to } \\
\text { stand }\end{array}$ & 4 & $4-5$ & $75 \%$ & $\begin{array}{l}\text { All tolerated the standing program well \& often showed displeasure when } \\
\text { the standing session was over. BMD increased in } 2 / 2 \text { children who } \\
\text { used dynamic stander \& } 1 / 2 \text { who used static stander, with increases in } \\
\text { the lumbar spine, proximal femur, and/or distal femur }\end{array}$ \\
\hline & Phase II & as above & $\begin{array}{l}\text { Effects of a dynamic versus } \\
\text { a static prone stander on } \\
\text { behaviour }\end{array}$ & as above & as above & $\begin{array}{l}\text { as } \\
\text { above }\end{array}$ & as above & $\begin{array}{l}\text { as } \\
\text { above }\end{array}$ & $\begin{array}{l}\text { Type of stander did not have an effect on Caroline Record of Individual } \\
\text { Behavior (CRIB) measures for any subjects. Staff reported that the two } \\
\text { subjects who stood in the dynamic standers in phase one were more } \\
\text { content and calm while standing }\end{array}$ \\
\hline
\end{tabular}


This is the authors' accepted version of a manuscript due to appear in a forthcoming issue of Journal of Applied Research in Intellectual Disabilities

\begin{tabular}{|c|c|c|c|c|c|c|c|c|c|}
\hline Theme $^{1}$ & $\begin{array}{l}\text { First author \& } \\
\text { year }\end{array}$ & Country & Study Focus & Study design & Key sample features & $\begin{array}{l}\text { Sample } \\
\text { size }\end{array}$ & $\begin{array}{l}\text { Age range } \\
\text { (mean (SD); } \\
\text { median) yrs }\end{array}$ & $\begin{array}{l}\% \\
\text { male }\end{array}$ & Key Findings \\
\hline$I(E)$ & Hatta 2007 & Japan & $\begin{array}{l}\text { Relationships between } \\
\text { postural adaptation of } \\
\text { patients \& configuration of } \\
\text { Seating Buggy's seating }\end{array}$ & \begin{tabular}{|l|} 
Postural \\
alignment of \\
participant \\
assessed \& \\
seating \\
support \\
surface \\
measured \\
using 3-D \\
scanning
\end{tabular} & $\begin{array}{l}\text { Profound } C P, \text { no independent mobility, } \\
\text { all had ID (usually severe). Average } \\
\text { period using the Seating Buggy } 5.3 \mathrm{yrs} \text {. }\end{array}$ & 21 & $\begin{array}{l}\text { 17-54 (37.6 } \\
\text { (ns); ns) }\end{array}$ & $57 \%$ & $\begin{array}{l}\text { Assessed fitting as appropriate or nearly appropriate for } 11 \text { \& ill fitting for } \\
\text { 10. Depth of thoracic support \& the forward distance of lumbar support } \\
\text { for those classed as ill-fitting were significantly reduced compared with } \\
\text { that of those where appropriate or nearly appropriate fitting }\end{array}$ \\
\hline I (0) & Hegarty 1997 & England & $\begin{array}{l}\text { Effects of relaxation training } \\
\text { vs rest for people with } \\
\text { severe/PMLD }\end{array}$ & $\begin{array}{l}\text { Within } \\
\text { subjects } \\
\text { quasi- } \\
\text { experimental }\end{array}$ & $\begin{array}{l}\text { Severe or profound ID \& physical or } \\
\text { sensory handicaps; } 6 \text { non-ambulant, } 4 \\
\text { ambulant with assistance }\end{array}$ & 10 & $\begin{array}{l}\text { 24-77 (ns } \\
\text { (ns); ns) }\end{array}$ & $30 \%$ & $\begin{array}{l}\text { Relaxation training appeared to produce greater relaxation effects than } \\
\text { rest. Postural measures (knee \& elbow angles) improved during } \\
\text { relaxation training for four people. Some clients with CP were able to } \\
\text { reduce muscle tone during relaxation training }\end{array}$ \\
\hline$S$ & $\begin{array}{l}\text { Humphreys } \\
2006\end{array}$ & $\begin{array}{l}\text { England } \\
\text { (North } \\
\text { Devon) }\end{array}$ & $\begin{array}{l}\text { Views of staff \& carers on } \\
\text { an integrated care pathway } \\
\text { (ICP) for 24-hr postural } \\
\text { management for children \& } \\
\text { adults }\end{array}$ & $\begin{array}{l}\text { Qualitative } \\
\text { focus groups }\end{array}$ & \begin{tabular}{|l|} 
Members of postural management \\
group who developed and/or \\
implemented ICP. Parent (1), paediatric \\
community physiotherapist (4), OT (3), \\
community childrens' nurse (1), \\
physiotherapy technical instructor (1), \\
physiotherapist in community team for \\
adult ID (1)
\end{tabular} & 11 & ns & ns & $\begin{array}{l}\text { Team members felt the ICP made members' intervention proactive } \\
\text { rather than reactive. The training package for all carers that was put in } \\
\text { place had been a keystone of the ICP \& provoked enthusiasm from all } \\
\text { members of the team. The training of respite carers was of concern to all } \\
\text { members of the team. The perception was that the ICP improved } \\
\text { service delivery \& will improve outcomes for children \& adults with motor } \\
\text { impairment }\end{array}$ \\
\hline$C$ & Kalen 1992 & US & $\begin{array}{l}\text { People with untreated } \\
\text { scoliosis }\left(>45^{\circ}\right) \text { compared } \\
\text { to those with mild or no } \\
\text { curves }\end{array}$ & \begin{tabular}{|l|} 
Between \\
subjects \\
comparison of \\
those with \& \\
without \\
scoliosis \\
curves of $>45^{\circ}$
\end{tabular} & $\begin{array}{l}56 \text { out of total } 62 \text { adults with severe } C P \\
\& \text { profound ID (49), severe }(6), \\
\text { moderate }(6) \& \text { mild (1). Group I } n=42 \\
\text { scoliosis }<45^{\circ} ; \text { group II } n=12 \text { scoliosis } \\
>45^{\circ}\end{array}$ & 56 & $\begin{array}{l}29-67(39 \\
\text { (ns); ns) }\end{array}$ & $42 \%$ & $\begin{array}{l}\text { Patients in the scoliosis group had more orthopaedic deformities } \\
\text { involving the pelvis \& hips \& needed modified wheelchairs more often } \\
\text { than did those without curves. There were no differences in incidence of } \\
\text { decubiti (pressure sores), highest functional level achieved, functional } \\
\text { loss, oxygen saturation, or pulse }\end{array}$ \\
\hline $\mathrm{C}$ & Kozma 2003 & US & $\begin{array}{l}\text { Medical conditions in non- } \\
\text { ambulatory people with } \\
\text { profound ID }\end{array}$ & \begin{tabular}{|l|} 
Cross \\
sectional \\
survey
\end{tabular} & $\begin{array}{l}\text { Non-ambulatory, institutionalized adults } \\
\text { with profound intellectual disabilities }\end{array}$ & 55 & $28-63$ (ns) & $47 \%$ & $\begin{array}{l}\text { Conditions included scoliosis }(62 \%) \text {, contractures }(42 \%) \text {, dislocation of } \\
\text { hips }(24 \%)\end{array}$ \\
\hline I (B) & $\begin{array}{l}\text { Lancioni } \\
2015\end{array}$ & Italy & $\begin{array}{l}\text { Effect of technology-aided } \\
\text { program on head \& trunk } \\
\text { forward bending (stimuli } \\
\text { contingent on appropriate } \\
\text { posture) }\end{array}$ & $\begin{array}{l}\text { Single subject } \\
\text { design }\end{array}$ & $\begin{array}{l}\text { Moderate to severe ID, congenital } \\
\text { encephalopathy with spastic tetraparesis } \\
\text { or hip \& legs impairments, spent day in } \\
\text { a wheelchair when head \& trunk tended } \\
\text { to be bent forward }\end{array}$ & 3 & $42,37 \& 23$ & $67 \%$ & $\begin{array}{l}\text { At baseline mean percentages of session time with presence of problem } \\
\text { posture were above } 80 \% \text { for all participants, dropping to below } 25 \% \text { (first } \\
\text { B }^{1} \text { ) \& about or below } 10 \% \text { (second } B^{1} \text { ) }\end{array}$ \\
\hline
\end{tabular}


This is the authors' accepted version of a manuscript due to appear in a forthcoming issue of Journal of Applied Research in Intellectual Disabilities

\begin{tabular}{|c|c|c|c|c|c|c|c|c|c|}
\hline Theme $^{1}$ & $\begin{array}{l}\text { First author \& } \\
\text { year }\end{array}$ & Country & Study Focus & Study design & Key sample features & $\begin{array}{l}\text { Sample } \\
\text { size }\end{array}$ & $\begin{array}{l}\text { Age range } \\
\text { (mean (SD); } \\
\text { median) yrs }\end{array}$ & $\begin{array}{l}\% \\
\text { male }\end{array}$ & Key Findings \\
\hline & & & pulmonary mechanics & \begin{tabular}{|l} 
quasi- \\
experimental \\
design
\end{tabular} & $\begin{array}{l}\text { for at least } 4 \text { weeks prior to testing, } \\
\text { prescribed SBO. All had severe or } \\
\text { profound cognitive impairment }\end{array}$ & & & & $\begin{array}{l}\text { sitting position without the orthosis ( } 1.2 \text { dynes } / \mathrm{cm}) \text {, suggesting that the } \\
\text { improved positioning achieved with the orthosis may decrease the work } \\
\text { of breathing }\end{array}$ \\
\hline I (P) & Littleton 2011 & US & $\begin{array}{l}\text { Effects of positioning } \\
\text { (supine, sitting, sidelying) } \\
\text { on respiratory measures }\end{array}$ & $\begin{array}{l}\text { Single subject } \\
\text { design }\end{array}$ & $\begin{array}{l}\text { Adolescents \& adults with CP } \\
\text { (quadriplegia) \& severe scoliosis, history } \\
\text { of respiratory illnesses. All with ID. } \\
\text { GMFCS V. No history of spinal } \\
\text { stabilization surgery \& not using spinal } \\
\text { orthoses }\end{array}$ & 5 & $\begin{array}{l}17-37(17 \\
22,25,26 \\
37)\end{array}$ & $60 \%$ & $\begin{array}{l}\text { Preference for sitting or } \mathrm{SL} \text { over supine differed depending on participant } \\
\text { \& outcome variables. } \mathrm{SAO}_{2} \text { was greater in sitting or } \mathrm{SL} \text { than supine for } \\
3 / 5 \text { participants. Further research with a larger sample is needed to } \\
\text { empirically link specific positions with improved respiratory efficiency }\end{array}$ \\
\hline I (E) & Lyons 2016 & $\begin{array}{l}\text { England } \\
\& \\
\text { Scotland }\end{array}$ & $\begin{array}{l}\text { Comfort when using } \\
\text { adaptive positioning } \\
\text { equipment }\end{array}$ & $\begin{array}{l}\text { Qualitative } \\
\text { case studies }\end{array}$ & $\begin{array}{l}\text { Parents, teachers, therapists \& key } \\
\text { support staff of children \& young people } \\
\text { with physical and ID; do not use } \\
\text { language; not all with CP but } 11 \\
\text { GMFCS V, } 2 \text { GMFCS IV }\end{array}$ & $\begin{array}{l}13 \\
\text { children }\end{array}$ & $\begin{array}{l}4-19 \\
\text { (approx) (ns } \\
\text { (ns); ns) }\end{array}$ & $46 \%$ & $\begin{array}{l}\text { Facial and vocal expressions were predominant for detecting } \\
\text { discomfort/comfort in most participants but whether discomfort from } \\
\text { equipment was present sometimes remained unclear. Threats to } \\
\text { comfort include the restrictive nature of some equipment, stretch } \\
\text { procedures \& positioning errors. Distress was not ignored. All parents } \\
\text { regularly attended to their child's needs during the night. Parents were } \\
\text { generally supportive of professionals using equipment to achieve health } \\
\text { and education related goals but also wanted periods of relaxation for } \\
\text { their children with time out of restrictive equipment }\end{array}$ \\
\hline$S$ & Maher 2011 & $\begin{array}{l}\text { South } \\
\text { Australia }\end{array}$ & $\begin{array}{l}\text { Special school setting } \\
\text { postural management: } \\
\text { benefits, barriers \& } \\
\text { facilitators, suggestions for } \\
\text { improvement }\end{array}$ & $\begin{array}{l}\text { Cross } \\
\text { sectional } \\
\text { survey }\end{array}$ & \begin{tabular}{|l|} 
Teachers, physiotherapists, \\
occupational therapists \& speech \\
pathologists caring for children with CP \\
aged 5-12 years, GMFCS level IV or V \\
at special schools for children with \\
significant intellectual \& physical \\
disabilities or special units within \\
mainstream schools, for children with \\
significant intellectual \&/or physical \\
disabilities.
\end{tabular} & 61 & ns & ns & $\begin{array}{l}\text { More benefits were reported by therapists than teachers. Apart from } \\
\text { 'comfort' \& 'general health', no other benefits were named by more than } \\
25 \% \text { of teachers. } 77 \% \text { of teachers thought one or two position } \\
\text { change(s) per day was optimal. Reported barriers included unavailability } \\
\text { of appropriate positioning equipment, education staff lacking the time } \\
\text { \&/or skills to carry out the programme \& insufficient communication } \\
\text { between education \& therapy staff. Integration of postural management } \\
\text { into the daily routine, provision of a written programme from therapy staff } \\
\& \text { increased communication between therapy \& education staff were } \\
\text { cited as facilitators }\end{array}$ \\
\hline I (E) & $\begin{array}{l}\text { McDonald } \\
2007\end{array}$ & England & $\begin{array}{l}\text { Parent \& primary therapist } \\
\text { perceptions of seating } \\
\text { equipment for children with } \\
\text { multiple \& complex needs }\end{array}$ & $\begin{array}{l}\text { Cross } \\
\text { sectional } \\
\text { survey }\end{array}$ & $\begin{array}{l}\text { Parents of children with severe CP (with } \\
\text { physical \& learning disabilities) \& } \\
\text { occupational therapist or a } \\
\text { physiotherapist who deals with the } \\
\text { child's seating \& positioning }\end{array}$ & 30 pairs & ns & ns & $\begin{array}{l}\text { Parents liked the chair for mainly environmental \& personal factors } \\
(n=25) \text {, with body structures second ( } n=16) \text {. Therapists liked the chair for } \\
\text { body structures }(n=27) \text { \& environmental/personal factors }(n=17) \text {. For } \\
\text { dislikes, there were } 60 \text { replies from parents \& } 32 \text { replies from therapists, } \\
\text { suggesting that parents who had to use the chairs had more experience } \\
\text { of problems. Parents were particularly concerned with the ease of use \& } \\
\text { practicalities of the seating system. These were not issues raised by the } \\
\text { therapists. Activity \& participatory factors were not mentioned. }\end{array}$ \\
\hline
\end{tabular}


This is the authors' accepted version of a manuscript due to appear in a forthcoming issue of Journal of Applied Research in Intellectual Disabilities

\begin{tabular}{|c|c|c|c|c|c|c|c|c|c|}
\hline Theme $^{1}$ & $\begin{array}{l}\text { First author \& } \\
\text { year }\end{array}$ & Country & Study Focus & Study design & Key sample features & $\begin{array}{l}\text { Sample } \\
\text { size }\end{array}$ & $\begin{array}{l}\text { Age range } \\
\text { (mean (SD); } \\
\text { median) yrs }\end{array}$ & $\begin{array}{l}\% \\
\text { male }\end{array}$ & Key Findings \\
\hline & 1992 & & $\begin{array}{l}\text { positioning on social- } \\
\text { communicative interactions } \\
\text { with staff }\end{array}$ & \begin{tabular}{|l} 
subjects \\
quasi- \\
experimental \\
design
\end{tabular} & $\begin{array}{l}\text { special education classes, unable to sit } \\
\text { independently, use assistive positioning } \\
\text { equipment during school day, } 9 / 10 \mathrm{CP} \text {. }\end{array}$ & & (ns); ns) & & $\begin{array}{l}\text { participants were in their wheelchair (small to medium effect size). } \\
\text { Position did not effect students' communication during unstructured } \\
\text { observations. Lowest functioning students communicated more whilst in } \\
\text { 'freestyle' (supine) during the structured observations (large effect size). } \\
\text { This latter finding was unexpected \& further investigation is needed }\end{array}$ \\
\hline \multirow[t]{2}{*}{ I (E) } & Neilson 2001 & Scotland & $\begin{array}{l}\text { Approaches for measuring } \\
\text { the effects of special seating } \\
\text { on people with profound \& } \\
\text { multiple disabilities \& their } \\
\text { carers }\end{array}$ & $\begin{array}{l}\text { Within } \\
\text { subjects } \\
\text { quasi- } \\
\text { experimental } \\
\text { design }\end{array}$ & $\begin{array}{l}\text { Adults with severe CP with profound ID, } \\
\text { unable to walk, extremely poor or no } \\
\text { postural stability with significant skeletal } \\
\text { deformities. } 8 / 9 \text { had previously used } \\
\text { molded seats \& received replacement } \\
\text { seats made to a new configuration }\end{array}$ & 9 & $\begin{array}{l}19-34(22.7 \\
(4.9) ; 20)\end{array}$ & $56 \%$ & $\begin{array}{l}\text { Patients benefited both physically \& functionally as a result of } \\
\text { customized molded seating. Benefits were apparent in terms of patients' } \\
\text { quality of life, sitting posture, feeding behavior, \& carer satisfaction with } \\
\text { the results. Benefits in quality of life were less apparent for carers than } \\
\text { for patients. }\end{array}$ \\
\hline & Neilson 2000 & Scotland & $\begin{array}{l}\text { Developing a model for } \\
\text { evaluating the impact of } \\
\text { surgical \& orthotic } \\
\text { intervention on the quality of } \\
\text { life of people with PIMD \& } \\
\text { their carers }\end{array}$ & as above & $\begin{array}{l}\text { Adults \& children with PIMD referred for } \\
\text { surgical, orthotic or wheelchair } \\
\text { interventions over a one year period, } 22 \\
\text { CP. } 8 \text { referred for surgical, } 6 \text { orthotic, } 9 \\
\text { seating, } 4 \text { wheelchair interventions }\end{array}$ & 27 & $\begin{array}{l}2-55 \text { (19 } \\
\text { (ns); ns) }\end{array}$ & $56 \%$ & $\begin{array}{l}\text { On the whole, } 62.5 \% \text { of carers were satisfied with the wide ranging } \\
\text { interventions. Carers satisfaction ratings in relation to 'posture' were } \\
\text { 'good, very good or excellent' (13) \& 'poor to fair' (3) }\end{array}$ \\
\hline I (S) & $\begin{array}{l}\text { Perlmutter } \\
1993\end{array}$ & US & $\begin{array}{l}\text { Proximal femoral resection } \\
\text { for subluxation or } \\
\text { dislocation of the hip }\end{array}$ & $\begin{array}{l}\text { Retrospective } \\
\text { review }\end{array}$ & $\begin{array}{l}\text { Older children undergoing proximal } \\
\text { femoral resection. } 11 \mathrm{CP} \text { spastic } \\
\text { quadriplegia, } 2 \text { myelomeningocele, all } \\
\text { non-ambulatory, all ID, all constant } \\
\text { chronic pain due to subluxated or } \\
\text { dislocated hips \& difficulty with perineal } \\
\text { hygiene due to limited hip passive } \\
\text { motion }\end{array}$ & 13 & $\begin{array}{l}6.5-16.2 \\
(11.7(\mathrm{~ns}) ; \\
\text { ns) at } \\
\text { surgery }\end{array}$ & ns & $\begin{array}{l}\text { Resections were either at the level of the neck ( } 9 \text { hips) or in the } \\
\text { subtrochanteric region ( } 10 \text { hips). The latter provided a better operative } \\
\text { result. Hygiene care improved for } 9 / 13 \text {. There were mixed results with } \\
\text { poor clinical results noted to be continued pre-operative pelvic obliquity, } \\
\text { postoperative adduction contracture, \& bony contact between the pelvis } \\
\& \text { the remaining proximal femur or its heterotopic ossification. Patients } \\
\text { with a satisfactory outcome did not demonstrate either pelvic obliquity or } \\
\text { bony impingement at the pelvis. } 6 / 13 \text { patients had a continued need for } \\
\text { pain medication \& all of these continued to demonstrate bony contact }\end{array}$ \\
\hline I (E) & Rennie 1992 & Scotland & $\begin{array}{l}\text { Effectiveness of a prototype } \\
\text { seating harness for } \\
\text { standard wheelchair }\end{array}$ & $\begin{array}{l}\text { Within } \\
\text { subjects } \\
\text { quasi- } \\
\text { experimental } \\
\text { design }\end{array}$ & $\begin{array}{l}\text { Adults who normally use a lap or crutch } \\
\text { strap, very severe learning disabilities }\end{array}$ & 10 & $\begin{array}{l}17-54(32.1 \\
\text { (ns); ns) }\end{array}$ & $50 \%$ & $\begin{array}{l}\text { All harnesses allowed less forward side than when no harness was } \\
\text { used. The prototype allowed significantly less movement than either of } \\
\text { the other harnesses }\end{array}$ \\
\hline I (S) & Sewell 2015 & England & $\begin{array}{l}\text { Activity \& participation after } \\
\text { spinal fusion for scoliosis }\end{array}$ & $\begin{array}{l}\text { Retrospective } \\
\text { cohort study }\end{array}$ & $\begin{array}{l}\text { Children with CP (GMFCS IV or V) \& } \\
\text { scoliosis Cobb angle }>40^{\circ} \text {. i. Operative } \\
\text { group } 25 / 34(75 \%) I Q<70 \text {; ii. seating } \\
\text { \&/or brace group } 21 / 36(58 \%) \text { IQ }<70 \text {. } \\
\text { All non-walkers }\end{array}$ & i. 34 & $\begin{array}{l}\text { i. } 10-17 \\
(13.9 \text { (ns); } \\
\text { ns); ii. } 8-17 \\
(12.1 \text { (ns); } \\
\text { ns }\end{array}$ & $\begin{array}{l}\text { i. } 59 \% \text {; } \\
\text { ii. } 53 \%\end{array}$ & $\begin{array}{l}\text { Activities Scale for Kids performance version (ASKp) improved in all } \\
\text { children who underwent surgery ( } P<0.01) \text {, mainly due to improved sitting } \\
\text { balance and less pain. In the nonoperative group, } 28 \text { of the } 36 \text { children } \\
\text { reported a reduction in the ASKp at } 2 \text { years }(P<0.01) \text {. There was a } \\
\text { reduction in the number of children experiencing pain in the operative } \\
\text { group. There was an increase in the number of children experiencing } \\
\text { pain in the nonoperative group. There was no difference in mobility, } \\
\text { GMFCS level, feeding, or communication in either group }\end{array}$ \\
\hline
\end{tabular}


This is the authors' accepted version of a manuscript due to appear in a forthcoming issue of Journal of Applied Research in Intellectual Disabilities

\begin{tabular}{|c|c|c|c|c|c|c|c|c|c|}
\hline Theme $^{1}$ & $\begin{array}{l}\text { First author \& } \\
\text { year }\end{array}$ & Country & Study Focus & Study design & Key sample features & $\begin{array}{l}\text { Sample } \\
\text { size }\end{array}$ & $\begin{array}{l}\text { Age range } \\
\text { (mean (SD); } \\
\text { median) yrs } \\
\end{array}$ & $\begin{array}{l}\% \\
\text { male }\end{array}$ & Key Findings \\
\hline & Sewell 2016 & England & $\begin{array}{l}\text { QoL after spinal fusion for } \\
\text { scoliosis }\end{array}$ & as above & $\begin{array}{l}\text { Children CP (GMFCS IV or V) \& } \\
\text { scoliosis Cobb angle }>40^{\circ} \text {. i. Operative } \\
\text { group } 15 / 18(83 \%) I Q<70 ; \text { ii. seating } \\
\text { adaptations \&/or bracing } 7 / 15(47 \%) \text { IQ } \\
<70 \text {. All non-walkers }\end{array}$ & $\begin{array}{l}\text { i. } 18 ; \\
\text { ii. } 15\end{array}$ & $\begin{array}{l}\text { i. } 10-16 \text { (14 } \\
\text { (ns); ns); ii. } \\
8-16(11 \\
\text { (ns); ns) }\end{array}$ & $\begin{array}{l}\text { i. } 50 \% \text {; } \\
\text { ii. } 47 \%\end{array}$ & $\begin{array}{l}\text { Nonoperative treatment was associated with a small decrease in carer- } \\
\text { assessed QoL over } 2 \text { years. Spinal fusion was associated with an } \\
\text { increase in QoL. Change in pain was the most significant factor affecting } \\
\text { QoL changes. There was no difference in mobility, GMFCS level, } \\
\text { feeding, or communication in either group }\end{array}$ \\
\hline I (B) & Shih 2011 & Taiwan & $\begin{array}{l}\text { Use of Wii Remote to } \\
\text { maintain upright head } \\
\text { posture via access to } \\
\text { preferred stimulation } \\
\text { (favourite videos) }\end{array}$ & $\begin{array}{l}\text { Single subject } \\
\text { design }\end{array}$ & $\begin{array}{l}\text { Severe multiple disabilities with spastic } \\
\text { quadriplegic CP, one with 'middle-level' } \\
\text { ID, one profound ID. Problems with } \\
\text { head posture but able to maintain } \\
\text { normal (or upright) head posture in order } \\
\text { to obtain preferred environmental } \\
\text { stimulation }\end{array}$ & 2 & $17 \& 18$ & $50 \%$ & $\begin{array}{l}\text { Both participants significantly increased their time duration for } \\
\text { maintaining upright head position (TDMUHP) to activate the control } \\
\text { system in order to produce environmental stimulation during the } \\
\text { intervention phases }\end{array}$ \\
\hline$C$ & $\begin{array}{l}\text { van } \\
\text { Timmeren } \\
2016\end{array}$ & $\begin{array}{l}\text { Nether- } \\
\text { lands }\end{array}$ & $\begin{array}{l}\text { Physical health problems in } \\
\text { people with severe or } \\
\text { profound intellectual \& } \\
\text { motor disabilities } \\
\end{array}$ & $\begin{array}{l}\text { Cross } \\
\text { sectional } \\
\text { survey }\end{array}$ & $\begin{array}{l}\text { Adults with severe or profound ID (IQ } \\
<35), \text { profound motor disability (fully } \\
\text { wheelchair dependent), \& impairments } \\
\text { in vision \&/or hearing }\end{array}$ & 99 & $\begin{array}{l}\text { Male ns (47 } \\
(16) ; n s) ; \\
\text { female ns } \\
(45(17) ; n s)\end{array}$ & $50 \%$ & $\begin{array}{l}\text { Spasticity }(76 \%(95 \% \mathrm{Cl} 67.6-84.4)) \text {, deformations (72\% (95\% Cl 63.2- } \\
80.8) \text {; scoliosis 56\%, hip 39\%) contracture }(32 \%(95 \% \mathrm{Cl} 22.8-41.2)) \text {, } \\
\text { decubitus/pressure area }(20 \%(95 \% \mathrm{Cl} 12.1-27.9))\end{array}$ \\
\hline $\mathrm{C} ; \mathrm{I}(\mathrm{P})$ & Waugh 2009 & England & Postural care at night & Case studies & $\begin{array}{l}\text { Case study i: male with severe scoliosis } \\
\text { contributing to premature death; ii. } \\
\text { female with severe scoliosis referred for } \\
\text { surgery for rods in spine whose family } \\
\text { adopted night time positioning }\end{array}$ & 2 & $\begin{array}{l}\text { i. } 3-23 ; \text { ii. } 9- \\
11 \text { yrs }\end{array}$ & $50 \%$ & $\begin{array}{l}\text { i. X-rays presented demonstrate progress from symmetrical body shape } \\
\text { at age } 3 \text { to severe scoliosis at age } 23 \text { shortly prior to death. Internal } \\
\text { capacity of thorax \& abdomen reduced such that right lung ceased to } \\
\text { function. Body shape distortion caused: pain \& discomfort; pelvic } \\
\text { obliquity \& rotation; disintegration of hips; respiratory failure; movement } \\
\text { of digestive organs into the space reserved for lungs; arrested peristaltic } \\
\text { movement leading to faecal impaction. ii. Pictorial illustration of severe } \\
\text { scoliosis being improved following night time positioning allowing for } \\
\text { spinal rod surgery to be avoided }\end{array}$ \\
\hline
\end{tabular}

$1 \mathrm{I}=$ intervention $(\mathrm{S}=$ surgery; $\mathrm{B}=$ behavioural; $\mathrm{E}=$ equipment; $\mathrm{P}=$ positioning' $\mathrm{O}=$ other); $\mathrm{S}=$ service related issues; $\mathrm{C}=$ characteristics of people with ID requiring postural care \& prevalence.

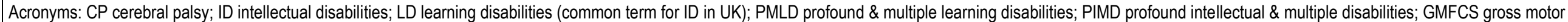
functioning classification system; SaLT speech \& language therapist; CN community nurse 